\title{
AGRONOMIC AND ENVIRONMENTAL PERFORMANCE OF MELON PRODUCED IN THE BRAZILIAN SEMIARID REGION ${ }^{1}$
}

\author{
VIVIANE DA SILVA BARROS ${ }^{2 *}$, TAYANE DE LIMA SANTOS ${ }^{3}$, EBENÉZER DE OLIVEIRA SILVA $^{4}$, JOÃO \\ ALENCAR DE SOUSA ${ }^{4}$, MARIA CLÉA BRITO DE FIGUEIRÊDO ${ }^{4}$
}

\begin{abstract}
This study evaluates the agronomic and environmental performance of yellow melons produced in an experimental area in Rio Grande do Norte, Brazil, using conventional methods and alternative systems of cultivation based on the rotation of melons with green manure crops. Two types of alternative management systems were evaluated, spanning twelve treatments: i) tillage, with the incorporation of the green manure biomass into the soil via the subsequent planting of melons into that residue, and ii) no tillage, with the maintenance of the biomass on the soil surface with subsequent planting of melons. Agronomic performance was evaluated by statistical analysis of productivity, while environmental performance was evaluated by analyzing the carbon footprint, according to ISO 14067. Agronomic analysis showed that rotation of melons with maize and Brachiaria resulted in a higher yield of melons for export. Assessment of the carbon footprint of this system in relation to the conventional system showed that the rotation system presented a lower carbon footprint. A scenario analysis showed that the carbon footprint can be further reduced by $42.54 \%$, if: i) production takes place in areas already cultivated for more than 20 years, ii) the amount of inorganic nitrogen applied is reduced by $50 \%$, and iii) commercialization of melons begins in the United States. This study shows the importance of rotating melons with green manure crops to increase production in the semiarid region and reduce the carbon footprint of this fruit.
\end{abstract}

Keywords: Carbon footprint. Climate change. Cucumis melo. Goldex.

\section{DESEMPENHO AGRONÔMICO E AMBIENTAL DO MELÃO PRODUZIDO NO SEMIÁRIDO BRASILEIRO}

\begin{abstract}
RESUMO - Esse estudo realiza avaliações agronômica e ambiental do melão amarelo, produzido em área experimental no Rio Grande do Norte, Brasil, em sistemas convencional e alternativo de cultivo baseado na rotação do melão. Dois tipos de manejo no sistema alternativo foram avaliados, considerando doze tratamentos com adubos verdes: i) incorporação ao solo da biomassa vegetal do adubo verde, e ii) manutenção dessa biomassa sobre o solo com posterior plantio do melão sobre a palhada. A avaliação agronômica baseou-se em análise estatística da produtividade, enquanto a ambiental, na análise da pegada de carbono, de acordo com a ISO 14067. A análise agronômica mostrou que a rotação de melão com milho e braquiária, obteve maior produtividade de melões tipo exportação. A avaliação da pegada de carbono dos sistemas mostrou que o sistema com rotação i) obteve a menor pegada de carbono quando comparado ao tratamento de referência. $\mathrm{O}$ estudo de cenários mostrou que a pegada pode ser reduzida em 42,54\%, se: i) a produção ocorra em áreas já cultivadas a mais de 20 anos, ii) a quantidade de nitrogênio inorgânico aplicado seja reduzida em 50\%, iii) e o melão passe a ser comercializado nos Estados Unidos. Esse trabalho mostra a importância de rotação do melão com adubos verdes para aumento da produção em região semiárida e redução da pegada de carbono.
\end{abstract}

Keywords: Pegada de carbono. Mudanças climáticas. Cucumis melon. Goldex.

\footnotetext{
${ }^{*}$ Corresponding author

${ }^{1}$ Received for publication in $12 / 04 / 2018$; accepted in $07 / 30 / 2019$.

Paper extracted from the doctoral thesis of the first author.

${ }^{2}$ Postgraduate Program in Natural Sciences, Universidade Estadual do Ceará, Fortaleza, CE, Brazil; vivianebarros1@hotmail.com -ORCID: 0000-0001-8309-9832.

${ }^{3}$ Department of Hydraulics and Environmental Engineering, Center of Technology, Universidade Federal do Ceará, Fortaleza, CE, Brazil; tayanedelimasantos@gmail.com - ORCID: 0000-0002-1905-6632.

${ }^{4}$ Embrapa Agroindústria Tropical, Fortaleza, CE, Brazil; ebenezer.silva@embrapa.br - ORCID: 0000-0002-7396-6637, joao.alencar@embrapa.br - ORCID: 0000-0003-3200-6143, clea.figueiredo@embrapa.br - ORCID: 0000-0002-9343-0370.
} 


\section{INTRODUCTION}

In Brazil, the semiarid regions produce $95 \%$ of the nation's melons. The states of Rio Grande do Norte accounts for $66.85 \%$ of national production, Ceará for $13.72 \%$, and Bahia for $10.53 \%$ (IBGE, 2017). The Northeast is the largest region of producers of melons for export. (MDIC, 2019).

Marketing of products with carbon footprint certification is being prioritized in the international market, especially for fruits like melons. Fruit and vegetable companies, such as Dole (DOLE, 2019) have already started to measure and reduce the carbon footprint of its products, keeping in mind the demands of importers and consumers for fruits with low impact on climate change. For instance, TESCO, a big fruit retailer in Europe, has targeted to reduce $7 \%$ of the carbon emissions along its supply chain (TESCO, 2017).

Carbon footprint analysis considers greenhouse gas (GHG) emissions over the life cycle of a product and their potential impact on climate change. The ISO 14067 standard (ISO, 2013) details principles, requirements, and guidelines for the quantification and communication of carbon footprint of products based on GHG emissions and removals over their life cycle, with climate change as the single impact category, allowing product certification.

Companies such as TESCO and Unilever have begun making comparative carbon footprint assessments of marketed products, resulting in a growing demand for carbon footprint studies along the supply chain.

Generally, this concept of a product life cycle is relatively new for Brazilian companies. Thus, the requirement for carbon footprint certifications can become a non-tariff barrier to Brazilian exports, compromising the socioeconomic sustainability of important agricultural chains, such as that of melon. Evaluating and identifying cropping systems with similar yield performances to current systems (conventional), but with lower climate change impact, that is smaller carbon footprint, is highly relevant.

Studies on the carbon footprints of Brazilian melons were conducted by Figueirêdo et al. (2013) and Santos et al. (2018), without considering the agronomic performance. The first study calculated the average carbon footprint of Brazilian melons produced under conventional systems of a sample of exporting farms in the Jaguaribe and Apodi region, in the Brazilian Northeast. Santos et al. (2018) compared the environmental and economic impacts of melons produced in the São Francisco Valley region with respect to conventional and alternative cropping systems.

In the present study, the agronomic (in terms of yield) and environmental performance (through carbon footprint) of yellow melon production for export was evaluated. Melons were grown under two cropping systems: i) conventional, which is based on monocropping and is characteristic of the Jaguaribe and Apodi region, and ii) alternative, based on melon rotation with green manure crops. Green manure is beneficial to the soil's physical (aggregation, humidity, soil density), chemical (increase in organic carbon, nitrogen, nutrient cycling), and biological (higher microbial and enzymatic activity) conditions (BELO et al., 2012; AITA; GIACOMINI; CERETTA, 2014).

The results of this study may help melon producers to identify the cropping system with the highest yield and lowest carbon footprint, thereby improving sales and reducing GHG emissions in agriculture. A low carbon agriculture was supported by the $5^{\text {th }}$ United Nations Conference of Parties (COP15, 2009) and the National Plan for Low Carbon Emissions in Agriculture (ABC Plan) (BRASIL, 2012).

\section{MATERIAL AND METHODS}

\section{Agronomic evaluation}

A field experiment was set up in an experimental unit consisting of a melon exporting farm located in the Jaguaribe-Apodi irrigation district. Three cultivations were performed in 2011, 2012, and 2013. The following data were collected for all cultivations: input use (e.g. fertilizer, electricity, diesel fuel, etc.), yield, fruit quality, and soil and plant carbon contents.

A split-plot randomized block design was used with four replicates. The plots $\left(864 \mathrm{~m}^{2}\right)$ consisted of two soil management systems and the sub-plots $\left(36 \mathrm{~m}^{2}\right)$ underwent twelve treatments. Different legume and grass species were chosen as green manure crops (Table 1). The soil management systems used for melon production in rotation with green manure crops were: i) tillage, with the incorporation of green manure biomass into the soil, and melon planting on plastic mulch, and ii) no tillage, without incorporating green manure biomass into the soil, and melon planting on green manure straw. 
Table 1. Plant species used as green manure crops for each treatment in the case of cropping systems with and without tillage of green manure.

\begin{tabular}{cc}
\hline Treatments & Plant species used as green manure crops \\
\hline 1 & Brown hemp (Crotalaria juncea L.) \\
2 & Millet (Pennisetum glaucum) \\
3 & Brown hemp (Crotalaria juncea L.) in intercropping with millet (Pennisetum glaucum) \\
4 & Corn (Zea mays) in intercropping with Brachiaria (Urochloa brizantha syn. Brachiaria brizantha) \\
5 & Conventional - Spontaneous vegetation incorporated into the soil, use of plastic mulch for melon production* \\
6 & Soil without vegetation \\
7 & Spontaneous vegetation, without plastic mulch for melon production \\
8 & Pigeon pea [Cajanus cajan (L.) Millspaugh] \\
9 & Pigeon pea [Cajanus cajan (L.) Millspaugh] in intercropping with millet (Pennisetum glaucum) \\
10 & Jack bean (Canavalia ensiformis) \\
11 & Jack bean (Canavalia ensiformis) in intercropping with millet (Pennisetum glaucum) \\
12 & Corn (Zea mays) in intercropping with Brachiaria (Urochloa brizantha syn. Brachiaria brizantha) with \\
\hline
\end{tabular}

*This treatment represents the common soil management adopted at the farm where this experiment was conducted.

Green manure crops were planted between April and May 2011, August 2012, and June 2013. Initially, corn (Zea mays) was intercropped with Brachiaria but after 30 days, other green manures were planted. The green manure biomass was desiccated before flowering as well as 30 days from the transplantation of melon seedlings. Crop management included fertilizer application, base fertilization with NPK 6:24:12, and pest and weed control. All biomass originating from green manure remained in the field, and grain was not collected except for corn, which was sold.

The production of melon seedlings took 8 days and consisted of sowing using coconut husk substrate, germination in controlled temperature, and seedling development in greenhouses (FIGUEIRÊDO et al., 2013). The seedlings were transplanted 30 days after the desiccation of green manure biomass. Melon seedlings of the Goldex variety were transplanted to the field and covered with polypropylene fabric for approximately 25 days to protect against pests. The fabric was removed at the beginning of pollination. Drip irrigation was used with emitters spaced at a distance of $0.35 \mathrm{~m}$ and having a flow rate of $1.7 \mathrm{~L} \mathrm{~h}^{-1}$. Based on soil chemical analysis and crop nutrient demand, fertilization was performed by fertigation, which is common practice by the producers in the region, without considering the nutrient input from green manure. In the conventional treatment (treatment 5, representing the conventional system applied in the Jaguaribe and Apodi region, Table 1), 5 t/ha of organic compost was applied. Weed control was performed by manual weeding, and pest and disease control were done by fungicide and insecticide spraying.

Harvest time was determined by analyzing the fruit soluble solid content in the field and evaluating whether it was higher than $9^{\circ}$ Brix; this was reached 60 to 65 days after planting melon seeds. Harvest was performed manually and each fruit was evaluated for its quality and classified as standard export fruit, internal market fruit, or scrap (fruit that did not meet the market quality criteria).

The overall average yields for the three years of export melon production were subjected to a variance analysis at $p \leq 0.05$ for each treatment. The effect of factors, such as treatment, year, cropping system (with or without green manure tillage), and interactions between them were analyzed. Averages were then compared using the Tukey test (at $\mathrm{p}$ $\leq 0.05$ ) to check whether there were significant differences among treatments.

The alternative cropping systems used for carbon footprint assessment were selected based on two criteria, namely melon yield and price of green manure crop seeds in the study region. The treatments that presented higher melon yields and used green manure crops with cheaper seeds at the local market were selected. These treatments were assumed to be more easily accepted by producers because of their lower cost.

\section{Environmental evaluation}

This analysis was based on carbon footprint, according to ISO 14067 (ISO, 2013).

The production system included (i) upstream processes, related to the production and transport of inputs to the experimental area (melon, grass and legume seeds, melon seedlings, fertilizers, pesticides, plastic, diesel, and electric power for irrigation); (ii) processes in the experimental area, related to green manure and melon production, and melon packing; and (iii) downstream processes, related to the transportation of melon to Europe (Figure 1).

The functional unit used was one ton of yellow melon packed and exported from the experimental area to the Rotterdam harbor, Holland.

Primary data related to green manure and melon production in the field were collected in the experimental area in Rio Grande do Norte $\left(4^{\circ} 52^{\prime}\right.$ 4.13" S, $37^{\circ} 20^{\prime} 16.94^{\prime \prime}$ W) from 2011 to 2013. Data for the selected cropping systems per hectare of exported melon produced are presented in Table A1.

Secondary data related to the production and 
transport of fertilizers, pesticides, plastic, and cardboard were obtained from the Ecoinvent v. 3.01 database (FRISCHKNECHT; JUNGBLUTH, 2007). The inventories for seed and melon seedling production and melon packing were obtained from Figueirêdo et al. (2013), who conducted a study in the same region as that of the experimental area in this study. The inventories for legume and grass seed, and biomass production were obtained from: (i)
França (2005) for Brachiaria brizantha (cv. Marandu); (ii) Valentini et al. (2009) for corn; and (iii) Souza et al. (2007) for pigeon pea.

GHG emissions, namely carbon dioxide $\left(\mathrm{CO}_{2}\right)$, methane $\left(\mathrm{CH}_{4}\right)$, and nitrous oxide $\left(\mathrm{N}_{2} \mathrm{O}\right)$ were estimated according to methodologies proposed by the IPCC (2006) using emission factors from national GHG inventories (MCT, 2010).

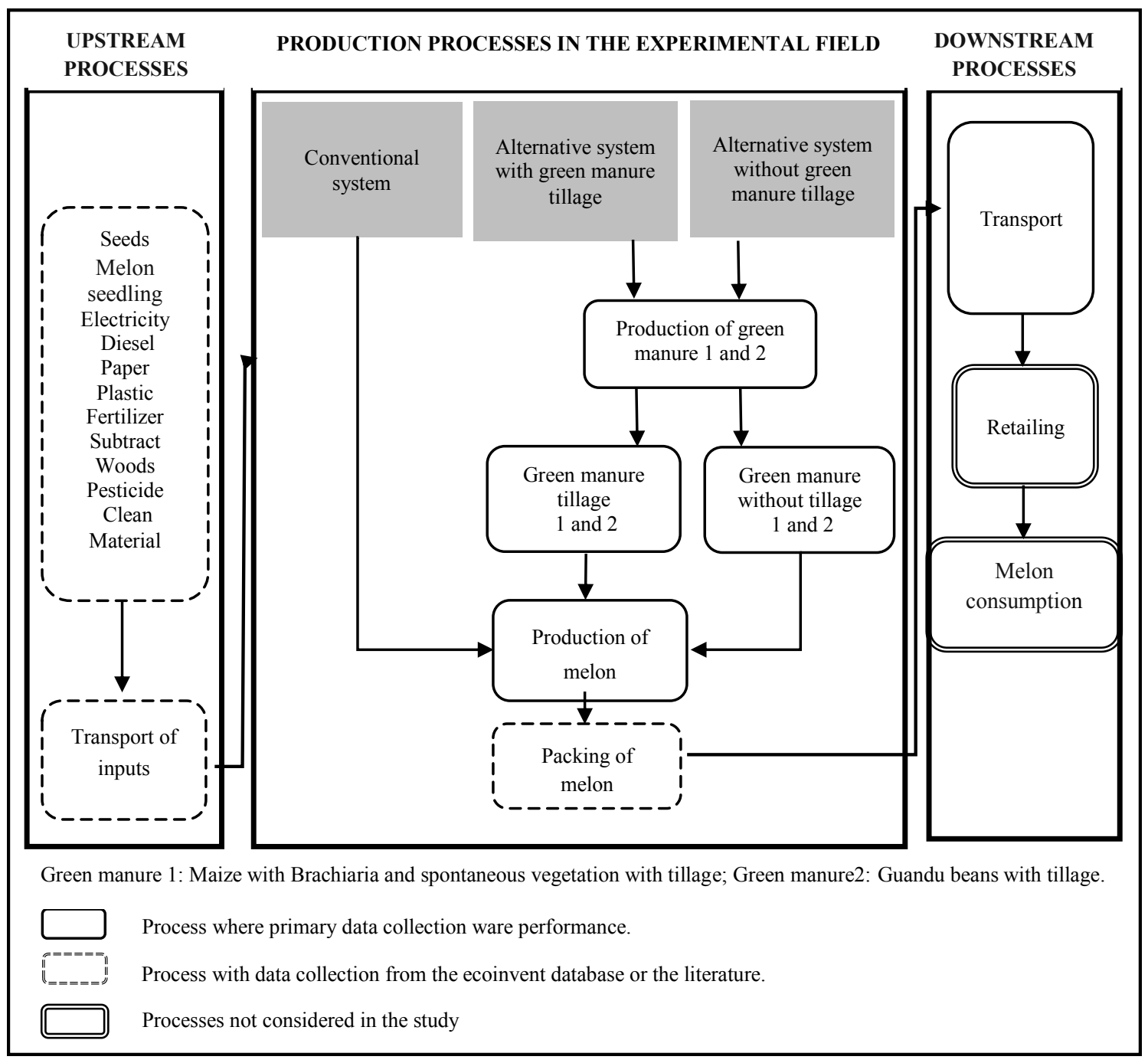

Figure 1. Studied system boundary.

The following GHG-emitting activities during melon production were considered: land use change (from caatinga to melon production area in the reference treatment), fertilization (organic and inorganic), burning of fossil fuels by tractors, and tillage of crop residues into the soil (green manure biomass and melon crop residues). To calculate the GHG emissions due to land use changes, $20 \%$ of the natural vegetation biomass (Caatinga vegetation, Savanna biome) was considered to have been burned, $70 \%$ mineralized, and $8 \%$ removed (NEMECEK et al., 2016).
The exported melons were transported by truck from the farm to the Pecém harbor in Ceará $(260 \mathrm{~km})$, and from there by ship to the Rotterdam harbor, Holland $(7465 \mathrm{~km})$. Melon transport by ship was undertaken in refrigerated containers with a $20 \mathrm{t}$ capacity.

Carbon footprint was calculated by multiplying the mass of each GHG by their Global Warming Potential for a period of 100 years (IPCC, 2006), which is expressed in kilograms $\mathrm{CO}_{2}$ equivalent, or $\mathrm{kg} \mathrm{CO}_{2}$-eq. Carbon footprint was determined using the software SimaPro 8.5.2. 
Pedigree matrix was used to calculate the geometric standard deviation for each parameter in the inventories, assuming that they follow a lognormal distribution. Moreover, the Monte Carlo method was used to evaluate the uncertainty in comparing carbon footprints between treatments. Differences between treatments A and B were considered significant when the carbon footprint value was higher for $\mathrm{A}$ than for $\mathrm{B}$ in at least $95 \%$ of the 1000 evaluations performed (GOEDKOOP et al., 2008).

After identifying the treatment with the lowest carbon footprint (reference treatment), the following alternative production scenarios were analyzed for this treatment:

- Scenario 1 (reduction of inorganic nitrogen fertilization): inorganic nitrogen fertilization of melon was reduced by $50 \%$, assuming that $50 \%$ of the nitrogen input from green manure is available for melon plants.

- Scenario 2 (land use changes): crops (green manure crops and melon) were considered to have been planted in an area that had been cultivated with temporary crops for more than 20 years, without emissions related to land use changes. This scenario was set because many areas cultivated with melon had been previously planted with watermelon and papaya.

- Scenario 3 (melon transport to the USA): destination of melons was changed from the Rotterdam harbor to the New York harbor (USA). In this scenario, melons were transported by ship from the Pecém harbor, covering a distance of $6139 \mathrm{~km}$. This route was set because of the potential consumer market of the state of Massachusetts, which has a short melon production season (July to September) and imports its melons from other countries.

- Scenario 4: joint evaluation of scenarios 1, 2 , and 3 .

\section{RESULTS AND DISCUSSION}

\section{Agronomic evaluation}

Analysis of variance of the treatments revealed significant effects of isolated factors, such as production year (YEAR), soil management system (SYST), and type of green manure (COVER), and significant interactions among the combined factors, namely YEAR*SYST and SYST*COVER (Table 2). There were no significant interactions between YEAR*COVER and YEAR*SYSTEM*COVER

Table 2. Variance Analysis.

\begin{tabular}{lccccc}
\hline \multicolumn{1}{c}{ SV } & DF & Sum of squares & Mean square & Cf & Pr $>$ Cf \\
\hline YEAR & 2 & 4630.522338 & 2315.261169 & 120.840 & $0.0000^{*}$ \\
SYST & 1 & 1409.097089 & 1409.097089 & 73.545 & $0.0000^{*}$ \\
COVER & 11 & 575.403278 & 52.309389 & 2.730 & $0.0025^{*}$ \\
BLOCK & 3 & 60.256275 & 20.085425 & 1.048 & $0.372^{\text {ns }}$ \\
YEAR*SYST & 2 & 482.761463 & 241.380732 & 12.598 & $0.0000^{*}$ \\
YEAR*COVER & 22 & 603.238887 & 27.419949 & 1.431 & $0.1021^{\text {ns }}$ \\
SYST*COVER & 11 & 523.257428 & 47.568857 & 2.483 & $0.0060^{*}$ \\
YEAR*SYST*COVER & 22 & 444.833045 & 20.219684 & 1.055 & $0.3987^{\text {ns }}$ \\
ERROR & 213 & 4081.032125 & 19.159775 & & \\
Corrected total & 287 & 12810.401928 & & & \\
CV $(\%)$ & 34.86 & & & & \\
\hline
\end{tabular}

*Non-significant $(\mathrm{P}<0.05)^{\mathrm{ns}}$.

SV - Source of variation; CV - Coefficient of variation; DF Degrees of freedom; Significant $(\mathrm{P}<0.05)$; SYST (cropping system, Cover (biomass); YEAR - production year; SYST - soil management system, encompassing tillage and no tillage; COVER - type of green manure.

Using the Tukey test $(\mathrm{p}<0.05)$ (Table 3$)$, an average comparison between the cropping systems and production years showed significant differences in melon yield between cropping systems with and without green manure biomass tillage for the years 2011 and $2012(\mathrm{p} \leq 0.05)$. This difference was mainly due to problems in the quality of fruit in the system without green manure tillage, where melons having skin spots were discarded.

For the remaining years (Table 3), melon yield decreased between 2011-2013 as well as between cropping systems due to the prolonged drought and water scarcity in the study region and the increased salinity of groundwater used in irrigation (water electric conductivity moved from 0.25 to $0.75 \mathrm{dS} / \mathrm{m}^{-1}$ ), which affected the mass of biomass resulting from green manure as well as the melon quality.

Using the Tukey test $(p<0.05)$, analysis of the average melon yield for different types of green 
manures (treatments) between and within cropping systems revealed significant differences between soil management systems for treatments $3,4,6,8,10,11$, and 12 (Table 4). The average melon yield for a three-year cycle was larger for the soil management system with green manure tillage. In the system without green manure tillage, melon plants exhibited decreased growth with smaller branches, which were likely to have directly affected photosynthetic rates. Fruit quality in this system was also affected, resulting in fruits with lower weights and increased frequency of skin spots that compromised their marketing in the international market, thereby directly affecting melon yield.

Similar to the conventional system, plastic mulch was used in the tillage system with green manure to decrease the contact of fruit with soil. In this system, melon plants presented no visual problems in growth rate, having benefited from the higher nutrient input by the incorporated straw. Fruit quality was also higher, meeting the standard for export and increasing melon yield.

Table 3. Comparison of average melon yield (t/ha) among cropping systems and production years (2011 to 2013).

\begin{tabular}{ccccccccc}
\cline { 3 - 7 } Cropping system & \multicolumn{9}{c}{ YEAR* } & Average \\
\cline { 3 - 7 } & \multicolumn{3}{c}{2011} & \multicolumn{2}{c}{2012} & 2013 \\
\hline With tillage & 22.04 & $\mathrm{aA}$ & 11.80 & $\mathrm{bA}$ & 10.47 & $\mathrm{bA}$ & 14.77 \\
Without tillage & 14.41 & $\mathrm{aB}$ & 7.45 & $\mathrm{bB}$ & 9.17 & $\mathrm{bA}$ & 10.34 \\
Average & 18.23 & & 9.63 & & 9.82 & & 12.56 \\
\hline
\end{tabular}

*Averages followed by the same lowercase letter within the same row, and uppercase letter within the same column, are not statistically significantly different according to the Tukey test, at $\mathrm{p} \leq 0.05$.

Table 4. Comparison of average melon yield (t/ha) between treatments, from 2011 to 2013, using the Tukey test.

\begin{tabular}{cccccc}
\hline Treatments & \multicolumn{2}{l}{ Without tillage } & \multicolumn{2}{c}{ With tillage } & Average \\
\hline 1 & 11.15 & $\mathrm{Aa}$ & 13.64 & $\mathrm{Aa}$ & 12.40 \\
2 & 12.09 & $\mathrm{Aa}$ & 15.10 & $\mathrm{Aa}$ & 13.60 \\
3 & 10.26 & $\mathrm{Aa}$ & 16.01 & $\mathrm{Ba}$ & 13.14 \\
4 & 9.95 & $\mathrm{Aa}$ & 16.60 & $\mathrm{Ba}$ & 13.28 \\
5 & 12.07 & $\mathrm{Aa}$ & 14.12 & $\mathrm{Aa}$ & 13.10 \\
6 & 6.50 & $\mathrm{Aa}$ & 14.64 & $\mathrm{Ba}$ & 10.57 \\
7 & 10.86 & $\mathrm{Aa}$ & 9.90 & $\mathrm{Aa}$ & 10.38 \\
8 & 9.12 & $\mathrm{Aa}$ & 15.13 & $\mathrm{Ba}$ & 12.13 \\
9 & 10.77 & $\mathrm{Aa}$ & 12.86 & $\mathrm{Aa}$ & 11.82 \\
10 & 9.22 & $\mathrm{Aa}$ & 17.70 & $\mathrm{Ba}$ & 13.46 \\
11 & 8.33 & $\mathrm{Aa}$ & 13.98 & $\mathrm{Ba}$ & 11.16 \\
12 & 13.78 & $\mathrm{Aa}$ & 17.50 & $\mathrm{Ba}$ & 15.64 \\
Average & 10.34 & & 14.77 & & 12.55 \\
\hline
\end{tabular}

Averages followed by the same uppercase letter within the same row and lowercase letter within the same column are not statistically significantly different according to the Tukey test, at $\mathrm{p} \leq 0.05$.

Treatments (types of green manure): 1) brown hemp, 2) millet, 3) brown hemp in intercropping with millet, 4) corn in intercropping with Brachiaria, 5) spontaneous vegetation tillage, and use of plastic mulch (conventional system used in the farm), 6) soil without vegetation, 7) spontaneous vegetation, without use of plastic mulch in melon production, 8) pigeon pea, 9) pigeon pea intercropped with millet, 10) jack bean, 11) jack bean intercropped with millet, 12) corn intercropped with Brachiaria, with tillage of the spontaneous vegetation present before green manure cultivation.

Giongo et al. (2016) showed that the practice of green manure with tillage also increased melon yield. They performed an experiment in Petrolina, Pernambuco, Brazil by rotating melon plants (variety 10/00) with two types of green manure: (i) $75 \%$ legumes and $25 \%$ non-legumes; and (ii) $25 \%$ legumes and $75 \%$ non-legumes, as well as spontaneous vegetation (conventional treatment). They also evaluated two types of soil management: tillage and no tillage of green manure biomass. They concluded that melon yield obtained without tillage of green manure was $13 \mathrm{t} / \mathrm{ha}$, and with tillage of green manure was $50 \mathrm{t} / \mathrm{ha}$.

The yields reported by Giongo et al. (2016) 
were higher than the ones found in this study, even if the first year of production was consider, which had no irrigation problems (treatments with green manure tillage resulted in $22 \mathrm{t}$ of melon/ha, Table 3 ). This may be explained by the fruit weight of the different melon varieties cultivated and the amount of nutrients from green manure in the compared studies. The fruit weight of the melon variety $10 / 00$ (demanded by the national market) was $2.8 \mathrm{~kg}$ on average, while the Goldex variety had an average weight of $1.4 \mathrm{~kg}$ (demanded by the international market) (COSTA; GRANGEIRO, 2010). Furthermore, the vegetal cocktail 1 used by Giongo et al. (2016) resulted in higher amount of nutrients to soil (174 kg of N/ha) than the amount obtained from green manure of corn intercropped with Brachiaria in 2011 for this study (147.30 kg of N/ha, according to Silva (2015).

Figueirêdo et al. (2013) demonstrated that the average melon yield in the Jaguaribe and Açu region was $23 \mathrm{t} / \mathrm{ha}$. This value was similar to the average yield in 2011 (year without drought) for the treatments involving green manure tillage in this study (22 t/ha, Table 3$)$. If the yield of treatment 12 $(28.63 \mathrm{t} / \mathrm{ha})$ in 2011 is compared to the average yield in the region, areas with green manure show better results.

Environmental assessment: carbon footprint analysis

Based on the criteria of higher melon yield and lower cost of green manure seeds, treatments 8 (pigeon pea) and 12 (corn in intercropping with
Brachiaria, with tillage of green manure and spontaneous vegetation present before green manure cultivation) were selected for carbon footprint analysis. Treatment 5 (conventional system) was compared with the selected treatments because, in this study, it represents the system currently in use at the melon farms in the Jaguaribe and Apodi region.

The average melon carbon footprint for the conventional system was $751 \mathrm{~kg} \mathrm{CO}$-eq/t melon, varying between 580 and $996 \mathrm{~kg} \mathrm{CO}$-eq/t melon (Figure 2). For the green manure system, the footprint of melon in treatment 8 was $690 \mathrm{~kg} \mathrm{CO}{ }^{-}$ eq/t, varying from 518 to $936 \mathrm{~kg} \mathrm{CO} \mathrm{CO}_{2}$-eq/t, whereas in treatment 12 it was $580 \mathrm{~kg} \mathrm{CO}$-eq/t, varying from 436 to $775 \mathrm{~kg} \mathrm{CO}$-eq/t.

The melon carbon footprint observed for the conventional cropping system was similar to values previously reported for melon in previous studies. Figueirêdo et al. (2013) evaluated melon monocropping in farms located in the Jaguaribe-Açu region and reported an average carbon footprint of $710 \mathrm{~kg} \mathrm{CO}$-eq/t melon. Santos et al. (2018) analyzed a conventional cropping system adopted in the region of São Francisco Valley, Brazil and calculated a carbon footprint of $754 \mathrm{~kg} \mathrm{CO}$-eq/t of melon.

Treatment 12, green manure with corn and Brachiaria in Table 1 presented the lowest average carbon footprint. The carbon footprint value of melon in this treatment was close to the one found by Santos et al. (2018). They evaluated the carbon footprint of melons produced in rotation with a mixture of legumes and non-legumes plants and obtained a value of $515 \mathrm{~kg} \mathrm{CO}_{2}$-eq/t of melon.

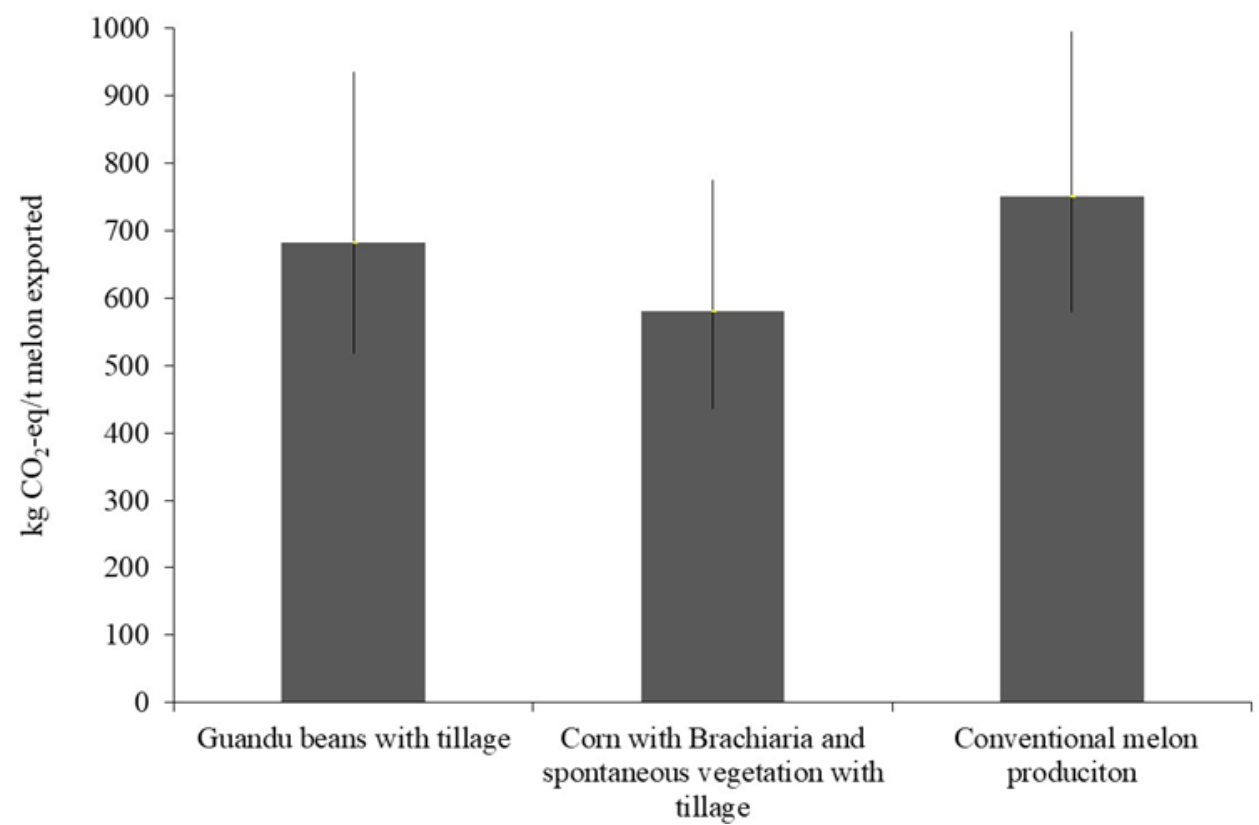

Figure 2. Carbon footprint $\left(\mathrm{CO}_{2}\right.$-eq/t melon $)$ and yellow melon yield $(\mathrm{t} / \mathrm{ha})$ in different cropping systems 
Although Treatment 12 resulted in the lowest average carbon footprint, the uncertainty analysis showed no significant difference between this treatment and the others (Figure 3).

Corn with Brachiaria and spontaneous vegetation with tillage (A) vs Guandu beans with tillage (B)

Conventional (A) vs Corn with Brachiaria and spontaneous vegetation with tillage (B)

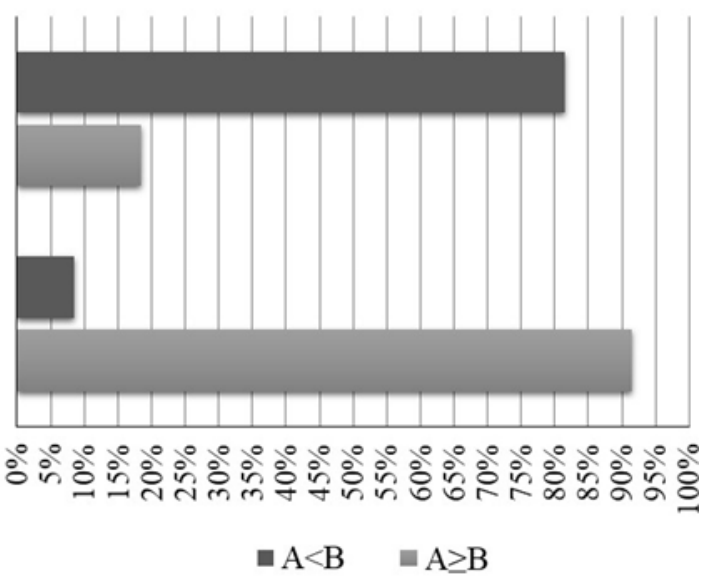

Figure 3. Error analysis for the comparison of the carbon footprint of melon production under alternative systems.

For the conventional and green manure cropping systems, the processes that occurred in the experimental area (land use changes, green manure, melon production, and packing) were the main contributors to carbon footprint (Figure 4a). Furthermore, most of these contributions originated from land use changes (Figure 4b).

GHG emissions during land use changes, especially $\mathrm{CO}_{2}$, resulted from biomass removal and burning, and organic matter mineralization, which resulted in decreased soil carbon and biomass during the replacement of native vegetation with the crop. GHG emissions during melon transport $\left(\mathrm{CO}_{2}, \mathrm{~N}_{2} \mathrm{O}\right.$,

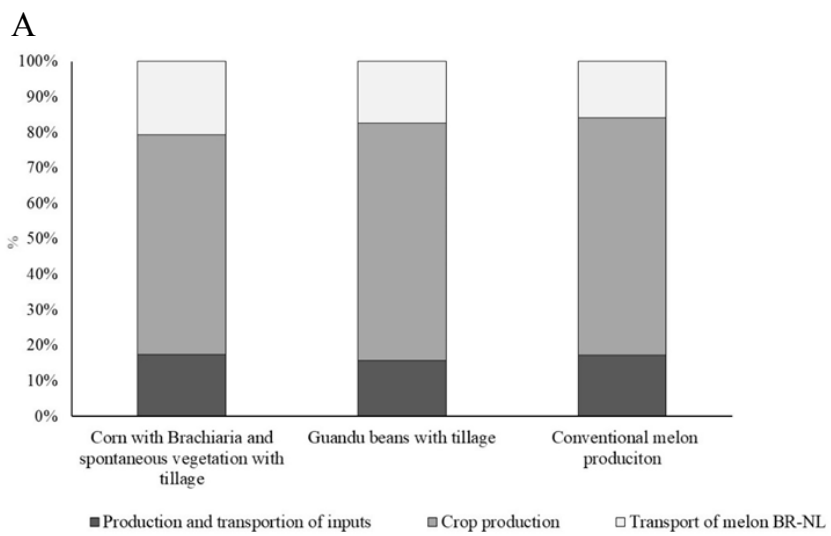

and $\mathrm{CH}_{4}$ ) were from the burning of fossil fuels by trucks (farm to harbor) and ship (Pecém harbor to Rotterdam harbor).

GHG emissions during melon packing $(10.9 \%)$ were related to the production and transport of cardboard boxes used in melon packing for export. GHG emissions during melon production mainly originated from the use of nitrogen fertilizers $(8 \%)$.

Details about the carbon storage in soil as well as the sources of each GHG during melon production, for the conservationist and conventional systems.

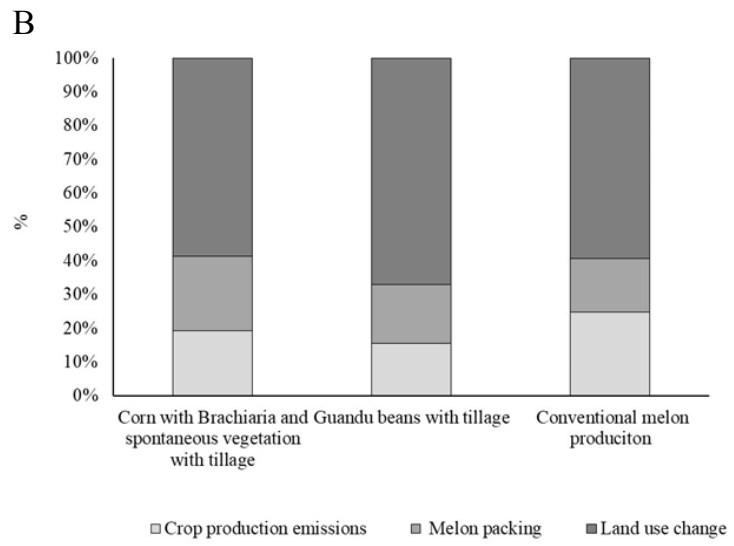

Figure 4. Contributions of the processes in the carbon footprint of the yellow melon in the reference system. a) Contribution of background, foreground, and downstream processes; b) Contribution of foreground processes.

Treatment 12 (green manure with corn and Brachiaria; Table 1) resulted in a higher melon yield and a lower carbon footprint. The secenario analysis was perfomed for this tratment to evaluate opportunities for reducing the footprint. All the evaluated scenarios resulted in reduced carbon footprint. The reduction in the footprint was higher for scenario $4(42.54 \%)$ because it consisted of simultaneous application of scenarios 1, 2, and 3 (Figure 5).

In scenario 1, corn and Brachiaria straw were considered to result in a $\mathrm{N}$ input of $114.18 \mathrm{~kg} / \mathrm{ha}$. 
This $\mathrm{N}$ input was calculated considering the average nutrient contents of dry biomass determined from samples collected at the experimental plots (SILVA, 2015). Based on the results obtained by Calonego et al. (2012), when biomass was incorporated into the soil, $35 \%$ of the total $\mathrm{N}$ present in corn and Brachiaria biomass was released. Corn with Brachiaria as green manure was concluded to be able to release $39.95 \mathrm{~kg} \mathrm{~N} / \mathrm{ha}$, which corresponded to $68 \%$ of the inorganic $\mathrm{N}$ applied to the melon plantation during the experiment. In this scenario, a reduction of only $50 \%$ of the total inorganic $\mathrm{N}$ applied was considered. This $\mathrm{N}$ reduction resulted in a $4 \%$ decrease in the carbon footprint of melon (Figure 5). However, to make sure that this reduction in nitrogen fertilization can be made without affecting yield, it is necessary to perform a new experiment with treatments using decreasing doses of the nitrogen fertilizer.

For scenario 2, which considered the use of an agricultural area that had been deforested over 20 years ago, a carbon footprint reduction of $36.32 \%$ was observed (Figure 5). This shows the importance of using areas that have already been deforested for agricultural production.

In scenario 3, where the destination of melons was the New York harbor, there was a carbon footprint reduction of $2.31 \%$ due to the shorter distance travelled.

A significant reduction in melon carbon footprint was observed under scenario 4, as compared to melon production under treatment 12 (green manure with corn and Brachiaria) or under treatment 5 (conventional system) (Figure A1 Annex A).

\section{Maize with Brachiaria and spontaneous vegetation with tillage}
Maize with Brachiaria and spontaneous vegetation with tillage $<50 \% \mathrm{~N}$

Maize with Brachiaria and spontaneous
vegetation with tillage $<$ Land Change

Maize with Brachiaria and spontaneous vegetation with tillag and Transported to the US

Maize with Brachiaria and spontaneous vegetation with tillage $<50 \% \mathrm{~N}<$ L and Change and Transported to the USA

\section{Conventional}

Figure 5. Scenario analysis of an alternative system with tillage of corn in intercropping with Brachiaria.

The results of the present study showed that melon rotation with green manure crops (pigeon pea and corn with Brachiaria) promoted a reduction in average melon carbon footprint (9 to $23 \%$ ) when compared to the conventional cropping system. This reduction resulted in higher melon yield, as the same amount of $\mathrm{N}$ was applied for melon production in both systems. When nitrogen fertilization of melon was decreased by $50 \%$ (scenario 1), the carbon footprint decreased by $4 \%$. Considering that the

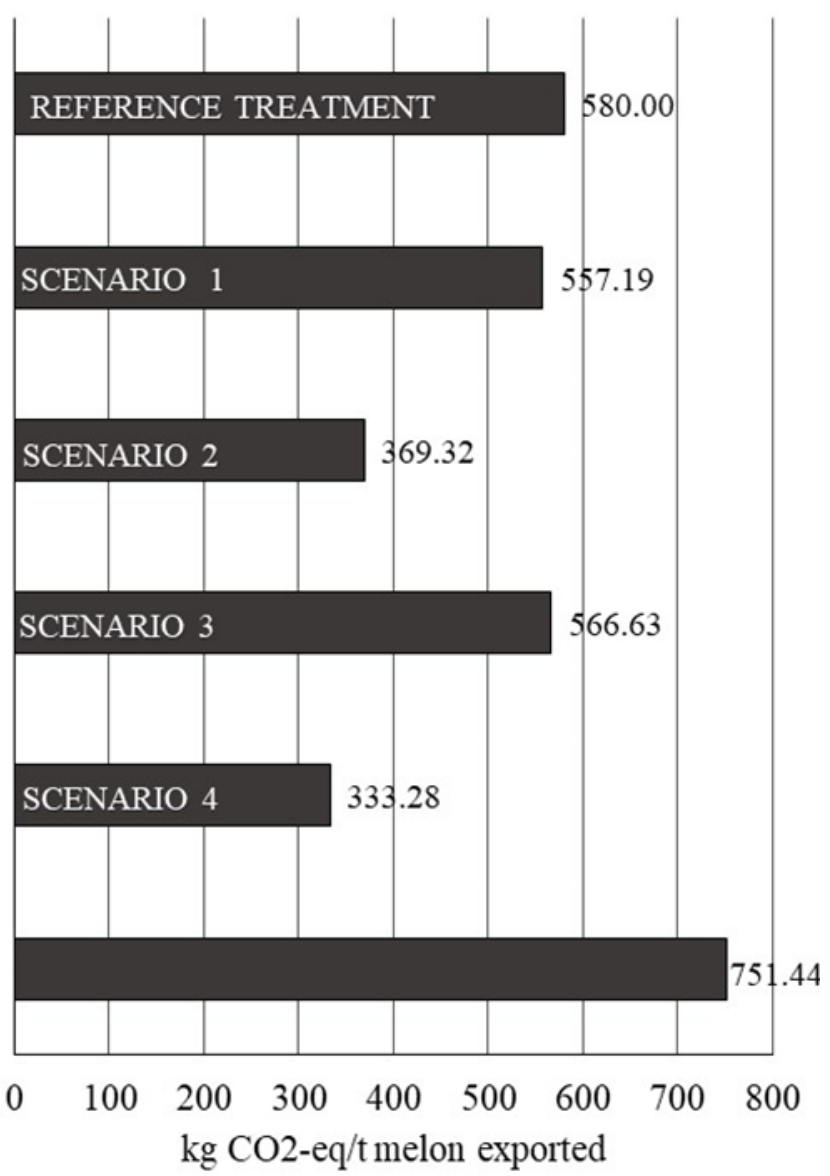

amount of $\mathrm{N}$ supplied by green manure is sufficient to meet $68 \%$ of the melon demand, a reduction higher than $4 \%$ in carbon footprint could be reached.

Nitrogen fertilization entails field nitrous oxide emissions in the fields. Because legumes fix atmospheric nitrogen, their growth does not require the use of synthetic fertilizers (JEUFFROY et al., 2013; FERREIRA NETO et al., 2017). It should be highlighted that green manuring is of great importance in the semiarid regions, where most soils 
are poor in organic matter and nutrients (GIONGO et al., 2016).

In the present study, although Brachiaria had a known potential for biological nitrogen fixation, NPK 6:24:12 was still applied for the development of corn because of the sandy soil in the region. The tillage of green manure biomass, which is rich in N, also allowed to reduce the fertilization requirements of melon. However, the traditional fertilization applied to melon plantations in the region was still performed, so that any variations observed between treatments would only be due to the introduction of green manure. Further studies should test the impact of this decrease in synthetic $\mathrm{N}$ fertilization for both corn and melon production, considering the $\mathrm{N}$ input from green manures.

Previous studies showed that growing legumes in temperate regions in rotation with cereals also led to reduction of the carbon footprint of both legumes and cereals (NEMECEK et al., 2008; NEMECEK et al., 2015). These authors found that growing peas and soybean in rotation with rapeseed, wheat, corn, and barley, in different legume and cereal combinations, reduced the overall impacts on climate change, especially due to reductions in the use of nitrogen fertilizers.

Comparison of melon carbon footprint with that of other fruits

American (TABATABAIE; MURTHY, 2016) or Asian (KHOSHNEVISAN et al. 2013) strawberries and pineapples from Costa Rica (INGWERSEN, 2012) and strawberries produced in the USA and Iran (in greenhouses) presented higher carbon footprints than melons produced in Brazil in Treatment 12, scenario 4, whereas pineapple from Costa Rica had a similar carbon footprint to the melon produced in this treatment.

Khoshnevisan et al. (2013) evaluated the carbon footprint of strawberries produced in Iran in open field and greenhouses. In both cases, straw was spread between rows of strawberry plants. The carbon footprint calculated was $585.19 \mathrm{~kg} \mathrm{CO}$-eq/t for open field-grown strawberries, and $695 \mathrm{~kg} \mathrm{CO}_{2}$ $\mathrm{eq} / \mathrm{t}$ for greenhouse-grown strawberries. Fertilizer application was the main contributor to the carbon footprint of open field-grown strawberries, whereas energy, followed by nitrogen fertilizer and irrigation water were the main contributors to the carbon footprint of greenhouse grown strawberries.

Tabatabaie and Murthy (2016) evaluated strawberries produced in the USA and concluded that the carbon footprint varied between California $(1.75 \mathrm{~kg} \mathrm{CO}$-eq $/ \mathrm{kg}$ strawberry), Florida $(2.50 \mathrm{~kg}$ $\mathrm{CO}_{2}$-eq/kg strawberry), North Carolina (5.48 kg CO -eq/kg strawberry), and Oregon $(2.21 \mathrm{~kg} \mathrm{CO}$-eq $/ \mathrm{kg}$ strawberry). This variation resulted from differences in yield and the management practices adopted in each region. GHG emissions resulting from the production of plastic materials and the use of diesel and fertilizers during production were the main contributors to strawberry carbon footprint.

Ingwersen (2012) evaluated the life cycle of pineapple produced in Costa Rica, with focus on carbon footprint and other environmental aspects. The functional unit adopted in the study was one serving of fruit (approximately $165 \mathrm{~g}$ ) and evaluation was performed using the Tool for Reduction and Assessment of Chemicals and Other Environmental Impacts (TRACI method). The carbon footprint was estimated to be $0.09 \mathrm{~kg} \mathrm{CO}_{2}$-eq, with a variation of \pm $0.04 \mathrm{~kg} \mathrm{CO}$-eq per functional unit. The farming stage was responsible for approximately $60 \%$ of the carbon footprint due to the application of nitrogen fertilizers and the use of fuel. Comparing the average carbon footprints of pineapple and melon (analyzed in the present study), using one $1 \mathrm{~kg}$ of fruit as reference, the carbon footprint of pineapple $(0.545$ $\mathrm{kg} \mathrm{CO}$-eq $/ \mathrm{kg}$ of pineapple) is close to that of melon produced in Brazil under a production system using green manure $\left(0.580 \mathrm{~kg} \mathrm{CO}_{2}\right.$-eq $/ \mathrm{kg}$ melon $)$.

\section{CONCLUSION}

The present study confirmed the importance of green manure in improving melon production and reducing its carbon footprint. The results highlighted the importance of changing monocropping systems to rotation systems with the addition of temporary and green manure crops to increase agricultural sustainability in the semiarid region.

With respect to green manure and conventional treatments, the melon yield analysis showed that melon grown in rotation with corn and Brachiaria, without removing the natural vegetation in the area between cultivations (treatment 12), achieved the best results. The carbon footprint analysis showed that this treatment generated a $23 \%$ lower carbon footprint than the conventional system. The treatment involving melon rotation with pigeon pea also resulted in carbon footprint reduction ( $9 \%$ ).

The scenario analysis showed that the carbon footprint for melon produced in treatment 12 can be further reduced by $42 \%$ if (i) the amount of nitrogen fertilization in the melon plantation is decreased by $50 \%$, (ii) plantations are established in areas that have been used for agricultural production for over 20 years; and (iii) melons are exported to regions closer to Brazil, such as the USA.

\section{ACKNOWLEDGEMENTS}

The authors thank the National Council for Scientific and Technological Development (Conselho Nacional de Desenvolvimento Científico e Tecnológico - CNPq), the Coordination for the 
Improvement of Higher Education Personnel (Coordenação de Aperfeiçoamento de Pessoal de Nível Superior- CAPES) and the State University of Ceará for funding this study, the Federal Rural University of the Semiarid Region for its partnership and support during the field work, and the melon producing companies from the Jaguaribe and Açu region for their technical support.

\section{REFERENCES}

AITA, C.; GIACOMINI, S. J.; CERETTA, C. A. Decomposição e liberação de nutrientes dos resíduos culturais de adubos verdes. In: FILHO, O. F. L. et al. (Eds.). Adubação verde e plantas de cobertura no Brasil: fundamentos e prática. 1ed. Brasília: EMBRAPA, 2014. p. 39-58.

BELO, E. S. et al. Decomposição de diferentes resíduos orgânicos e efeito na atividade microbiana em um latossolo vermelho de cerrado. Global Science and Technology, v. 05, n. 3, p. 107-116, 2012.

BRASIL, C. N. A. Confederação da Agricultura e Pecuária do Brasil Guia de Financiamento para agricultura de baixo carbono / Confederação da Agricultura e Pecuária do Brasil. v. 1, p. 44, 2012.

BRASIL, MINISTÉRIO DA CIÊNCIA E TECNOLOGIA - MCT. Inventário Brasileiro de Emissões Antrópicas por Fontes e Remoções por Sumidouros de Gases de Efeito Estufa não Controlados pelo Protocolo de Montreal. Brasília: MCT, 2010.

BRASIL MINISTÉRIO

DO DESENVOLVIMENTO, INDÚSTRIA E COMÉRCIO - MDIC. Sistema de Análise das Informações de Comércio Exterior). Brasília. Disponivel em: <http://comexstat.mdic.gov.br/pt/ geral>. Acesso em: 29 Agosto. 2019.

CALONEGO, J. C. et al. Persistence and nutrient release from maize, Brachiaria and lablab straw. Bioscience Journal, v. 28, n. 5, p. 770-771, 2012.

COP15-COPENHAGEN,

UNFCCC. Methodological guidance for activities relating to reducing emissions from deforestation and forest degradation and the role of conservation, sustainable management of forests and enhancement of forest carbon stocks in developing countries. 2009. Disponível em: <https://unfccc.int/resource/ docs $/ 2009 /$ cop15/eng/11a01.pdf\#page=11>. Acesso em: 27 out. 2018 .

COSTA, N. D.; GRANGEIRO, L. C. Sistema produção Melão - Cultivares. Disponível em:
$<$ http://www.cpatsa.embrapa.br:8080/ sistema_producao/spmelao/cultivares.html $>$. Acesso em: 29 jul. 2019.

DOLE. Carbon footprint: Initiatives at Dole Fresh Vegetables. 2019. Available at: $<$ http://dolecrs.com/ sustainability/carbon-footprint/initiatives-at-dolefresh-vegetables/>. Accessed on: 29 July 2019.

FERREIRA NETO, A. R et al. Nitrogen fixation of Poaceae and Leguminoseae in a green manure experiment in the Brazilian semiarid region. Australian Journal of Crop Science, p. 1474-1480, 2017.

FIGUEIRÊDO, M. C. B. et al. The carbon footprint of exported Brazilian yellow melon. Journal of Cleaner Production, v. 47, p. 404-414, 2013.

FRANÇA, L. V. Viabilidade de produção de sementes de Brachiaria brizantha Stapf cv. Marandu em Cabeceiras - GO. $1^{\circ}$ ed. Planaltina, DF: UPIS, 2005. 35 p. (Boletim técnico).

FRISCHKNECHT, R.; JUNGBLUTH, N. Ecoinvent e Overview and Methodology. Swiss Center for Life Cycle Inventories, Dubendorf. 2007.77 p.

GIONGO, V. et. al. Soil management systems for sustainable melon cropping in the submedian of the São Francisco Valley. Revista Caatinga, v. 29, n. 3, p. 537-547, 2016.

GOEDKOOP, M.et al. SimaPro Tutorial. Netherlands: Pré-Consultants, 2014.

INGWERSEN, W. Life cycle assessment of fresh pineapple from Costa Rica. Journal of Cleaner Production, v. 35, p. 152-163, 2012.

INSTITUTO BRASILEIRO DE GEOGRAFIA E ESTATÍSTICA - IBGE. Sistema IBGE de Recuperação Automática - SIDRA: Agropecuária: Produção Agrícola Municipal. 2017. Disponível em: ttp://www.sidra.ibge.gov.br/Tabela/1612> Acesso em: 26 Agosto. 2019.

INTERNATIONAL PANEL ON CLIMATE CHANGE (IPCC), 2006. Guidelines for National Greenhouse Gas Inventories. IPCC, Geneva. Available at: <http://www.ipcc-nggip.iges.or.jp/>. Accessed on: 20 February 2014.

INTERNATIONAL ORGANIZATION FOR STANDARDIZATION - ISO 14067:2013 Greenhouse gases - Carbon footprint of products - Requirements and guidelines for quantification and communication. Geneva: ISO 14067, 2013.

JEUFFROY, M. H. et. al. Nitrous oxide emissions 
from crop rotations including wheat, rapeseed and dry peas. Biogeosciences, v.10, p. 1787-1797, 2013.

KHOSHNEVISAN, B. et al. Environmental impact assessment of open field and greenhouse strawberry production. European Journal of Agronomy, v. 50, p. 29-37, 2013.

NEMECEK, T. el al. Designing eco-efficient crop rotations using life cycle assessment of crop combinations. European Journal of Agronomy, v. 65 , p. 40-51, 2015.

NEMECEK, T. et.al. Environmental impacts of introducing grain legumes into European crop rotations. European Journal of Agronomy, v. 28, p. 380-393, 2008.

SANTOS, T. L. et al. Cleaner fruit production with green manure: The case of Brazilian melons. Journal of Cleaner Production, v. 181 p. 260-270, 2018.

SILVA, A. R. C. Acúmulo de matéria seca e nutrientes em plantas de cobertura do solo e meloeiro em sistemas de cultivo. $2015.81 \mathrm{f}$. Tese (Doutorado em Agricultura Tropical) - Universidade Federal Rural do Semi-Árido, Mossoró, 2015.

SOUZA, F. H. D. et al. Produção de sementes de Guandu. São Carlos: Embrapa Pecuária Sudeste, 2007. 68 p.

TABATABAIE, S. M. H.; MURTHY, G. S. Journal of Cleaner Production, v. 127, p. 548-554, 2016.

TESCO. Little helps plan: working together to make a big difference. 2017. Disponivel em: $<$ https://www.tescoplc.com/media/468161/littlehelps-plan_online.pdf $>$. Acesso em: 29 July 2019

VALENTINI, L. et al. Produção de sementes de milho variedade para uso próprio em propriedades de microbacias hidrográficas. Niterói, RJ: 2009. 16 p (Programa Rio Rural-Manual Técnico, 15). 